\title{
THE FIVE ACT TRAGEDY: THE FRENCH IN INDO-CHINA, 1945-54
}

S. Monick*

\begin{abstract}
'It will be enough for me if these words of mine are judged useful by those who want to understand clearly the events which happened in the past and which (human nature being what it is) will at some time or other and in much the same ways, be repeated in the future.'
\end{abstract}

\section{(Thucydides: The Peoloponnesian War)}

Thucydides wrote those words 2500 years ago. In his book, concerned with the thirty year Spartan-Athenian conflict, which ultimately destroyed Athens, he focused attention upon the Syracuse expedition. It was a tale of military miscalculation, egotism, conflicting personalities, and ultimate destruction. The French were to recreate Thucydides' history between 1946 and 1954 , thus lending weight to the opening words of this chapter. The French collapse in Indo-China has perhaps faded somewhat from the memories of military observers, in view of the more recent American debacle in Vietnam. It nevertheless remains of crucial interest to all concerned with insurgency. For the victory of the Vietminh represents an archetypal model of terrorist insurgency upon the Communist pattern, structured according to a five point plan. Analysis of this model (and, in particular, of the French failure to counteract it), will assist in refuting Thucydides' assertion that 'events which happen in the past. . . will be repeated in the future. What follows, therefore, is not a campaign history of the Indo-Chinese War, but rather an analysis motivated by this central objective.

Whilst Ho Chi Minh was the political leader of the Vietminh uprising, Vo Nguyen Giap was its military leader. Giap, who had been a political refugee from French Indo-China, had learnt the basic rules of guerilla and revolutionary warfare from Mao Tse Tung, at the latter's headquarters and guerilla training school at Yenan, from which, between 1945 and 1949, Mao successfully conducted the war against the nationalist Kuomintang. The essence of Mao Tse Tung's strategy was that operations against a superior 'imperialist' enemy ought to evolve through five well defined stages. It was the Vietminh strategy, modelled upon these five stages, which determined the course of the Indo-China conflict. These five stages were:

\section{Mobilization of the masses:}

This phase may be sub-divided into two stages: the birth of the ideal, and the translation of the ideal into a mass movement. With regard to the first sub-division of this phase, it should be observed that any political upheaval - be it the advent of Christianity, Mohammedanism, Fascism, - is initiated by the birth and crystallization of an ideal which, initially, is startlingly revolutionary and antithetical to all established thought and practices of the time. (In Indo-China this ideal was, of course, Chinese-inspired Asian Communism). Its growth is invariably clandestine, as it fructifies in a hostile political environment. (Occasionally such upheavals embody the revival of religious-political-social movements which had apparently been exhausted by historical processes. A vivid example of this phenomena is the revival of Mohammedanism, manifested in the Iran insurgency; and reproducing the violent anti-European sentiment which characterized the Arab conquest of the Byzantine empire in the 7th century AD. It is perhaps this sentiment, and the Moslem-revival which it embodies, which fundamentally motivates the oil blackmail of the West by OPEC states). In Indo-China this environment was, of course, French colonial rule, dating from 1863 , which comprised the provinces of IndoChina - Tonkin, Annam, and Cochin-China, as well as Laos and Cambodia. The ideal was born in 1925, in the form of the Indo-Chinese Communist Party, founded by an itinerant revolutionary variously named Nguyen Van Thanh, or Van Cung, or Tat Thanh Ai Quoc, but now universally known as Ho Chi Minh. The ultimate object of his party was a Communist organized state, totally independent of French rule. Between 1925 and 1930, Ho Chi Minh had established an effective network in the villages and small towns of the Red River Delta, in the Tonkin province of the north. The result of this political activity was serious disturbances in 1930, known as the Yen Bay mutiny which, although premature and abortive, took two years to suppress and cost the lives of some 10000 Vietnamese, and the imprisonment of some 10000 more. After this abortive rising, Ho Chi 
Minh escaped, first to Siam, and ultimately to China, there to establish contact with Mao. It was in China (at Kwangsi) that the party formulated its objectives and political programme. (It was at Kwangsi, in 1939, that Giap met Ho Chi Minh). This programme was largely based upon the five point plan elucidated in Mao's 'Guerilla warfare', written in 1937, just after the famous 'Long March'. A policy identical to Mao (i.e. of relying completely upon the rural population to form the base and substance of the revolution).

Indo-China was no exception to the violent upsurge of anti-colonialist feeling which succeeded World War 2. European prestige had been irrevocably destroyed by the humiliation inflicted by the Japanese in the former British, Dutch, and French dependencies in the Far East. Although not sufficiently strong in 1945 to challenge the French re-occupation of Indo-China, the severe 'oss of prestige suffered by the French during the war (its tiny garrison being initially tolerated by the occupying Japanese, and then subsequently arrested) ensured that the Vietminh had gained a decisive psychological advantage in the eyes of the local populace. The massacre, in September, 1945, of four to five hundred Europeans in Saigon by Vietnamese nationalists was symptomatic of this waning prestige. The French presence was further undermined by an agreement with $\mathrm{Ho}$ Chi Minh in March, 1946, by the terms of which independence of the Republic Vietnam was recognised, in return for the re-occupation. This led to the situation in which French forces were fighting within a political vacuum. (The political vacuum created by the surrender of the Japanese, had left the Vietminh as the only viable political-military force, esconced in Tonkin, with a force of 30000 men).

However, how was the ideal to be translated into a mass movement? The answer resided in a process termed by the French 'pourissement' ('process of rotting'). This process was initiated in 1946 (after Giap had launched a totally premature conventional offensive against Hanoi in December, 1945, with disastrous consequences). The objects of 'pourissement' were - and are - to destroy the functions of government in any chosen area, and to transfer the loyalty of the population to the terrorists. The methods are multiple - the assassination of government appointed headmen, schoolteachers, and other local officials; the interruption of tax-paying to the government; the intimidation of the village council. The Vietminh developed this calculated policy of intimidation into a policy of encouraging nationalist feeling, political 'education' (indoctrination would, perhaps, be a more appropriate term), the provision of medical and welfare services, and the formation of a village militia - in short, the creation of a 'state within a state', a favourite technique of communist insurgency. The militia had three roles: to commit the village, through the commission of hostile acts against the 'imperialists' irrevocably to the communist side; to weaken the power of the established government militarily; and to provide recruits for the next echelon of the party's armed forces the 'regional forces', which were the major instrument of the second stage of the Indo-China insurgency.

\section{Guerilla Warfare:}

This assumed the form of ambushes against French military patrols and convoys. At the beginning of the war (during the years 1947-9), the principal locality for the war of ambushes lay along the frontier with China, where the need to provision a series of fortress towns compelled the French to maintain regular convoys through the mountains and heavily wooded defiles of the 'route coloniale 4'; a road which connected several French posts to the north-east of Tonkin, on a ridge adjacent to the Chinese frontier. In point of fact, the defence of RC4 sandwiched many thousands of French soldiers between the neutral - but potentially hostile - China and the Vietminh Vastness of the Viet Bac mountains. These mountains were the training base of the Vietminh recruits. The French could not penetrate this area, into which a stream of Vietminh personnel, which had proved themselves in the village militias and 'regional forces' came for training in 'regular' warfare. Thus, Giap's regular army was reinforced steadily, and constantly practiced in the art of regular warfare, which had miscarried in December, 1945; whilst the French were shackled to the debilitating static defence of lines of communication (in the form of road opening). The second form which this stage of the war assumed was the 'geurre des postes'; the attacks upon the French 'postes'. For if there is a visual trademark of the Indo-Chinese war, it is that of the 'poste'; a square or rectangular stockade of split and sharpened bamboo, a ditch beyond, some earthworks within, a bamboo watchtower in the centre of it, with, at its summit, the tricolour, at its foot the house of the commander.

It was during this period of guerilla warfare that the French defeat germinated, for two closely interrelated reasons. First, it enabled the Vietminh 
to consolidate and develop their regular forces, until they reached a level of equipment and manpower with which the French could not compete. Secondly, it nurtured the Vietminh forces until the Chinese Communist Victory in 1949. In the final months of 1949, the absolute French monopoly of access to heavy equipment and supplies was to be broken. For in October of that year, the vanguard of the Chinese Red Army, victorious in the civil war with Chiang-Kai-Shek, arrived at the frontier along the entire length of
RC4, and at once established contact with their brother Communists of the Vietminh. The Chinese, predictably, offered advice, training, arms and supplies. The strength of Giap's main force ('chu-luc') was at this point approximately 100000 , and he began to organize it, with Chinese assistance, into five divisions, on European lines, of which four were to be located in the Viet Bac. It was to be the Chinese supplied artillery and ammunition which were to pen up the French in their self-engendered trap of Dien Bien

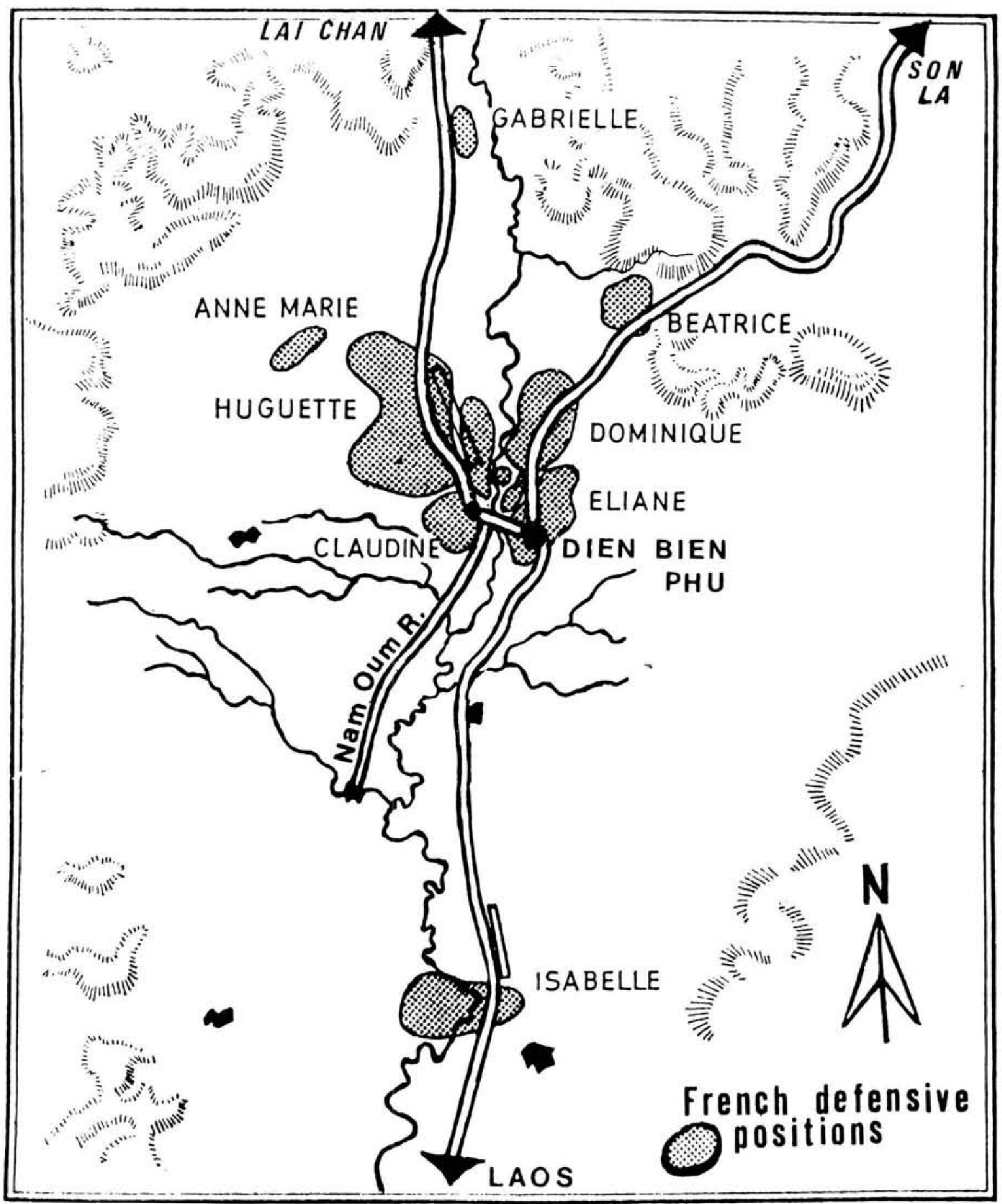


Phu. The Chinese presence also provided the Vietminh with powerful moral succour. For $\mathrm{Ho} C h i$ Minh, Giap, and their movement were no longer an isolated band beleagured within the territory of the 'imperialists', and sustained only by hopes. (The dependence of a terrorist movement upon sympathetic states, discussed in Section 1 of Chapter 1, within the context of the domino theory, is exemplified in the Rhodesian situation; although, in this instance, the neighbouring states are themselves the long-range instruments of continental powers - notably the USSR. A further example is the Greek Communist insurgency of 1944-9, which was heavily dependent upon arms and supplies from neighbouring Communist Yugoslavia - itself a channel for Soviet supplies, until the Tito-Stalin split of 1949).

Yet this phase of the war might have been won, had not the French military mind been obsessed with the defensive mentality. This approach was illustrated in a strategy which focused upon defence of lines of communication (notably RC 4) and the system of defensive 'postes'. The apotheosis of this corrosive defensive mentality was the Verdun-inspired fortress of Dien Bien Phu. This defensive mentality has its roots in the traditionalist French military mind, and is symptomatic of the mentality which seeks to hold a clearcut line against guerilla activity, behind which government forces can move freely and openly. The negation of this offensive spirit leads to a military fatalism, smothering initiative; a point discussed in some detail in Section 2 of Chapter 1. For in the ideal terrain of the guerilla - the jungles and paddy fields of Indo-China, the virgin bush of Mozambique, Angola, and Rhodesia the small scale guerilla tactics will always penetrate this shield. Yet an offensive 'search and destroy' approach, based upon small tactical units might well have crushed this phase of the Vietminh insurgency; thereby ending the psychological advantage which the latter enjoyed in the eyes of the populace, re-asserting French control over the hamlets and villages, and, with the hinterland secure, enabling the French to concentrate on an assault upon the nascent regular forces in the Viet Bac (employing the same tactical units to locate and destroy the enemy, as opposed to the lumbering armoured columns of which both the French and their American successors were so fond).

It is pertinent to ask: what was the source of this inability to adapt strategy and tactics to the Indo-Chinese terrain (the 'sea' of the conflict, to employ Mao's terminology)? First, it must be admitted that guerilla warfare in 1946 had not developed into the archetypal assault upon sophisticated military technologies. The Chinese Communist assault upon the Kuomintang during the 1920s and 1930s, and the Greek Communist insurgency of 1944-9 furnished examples, but the problems of Mozambique, Angola, Algeria, Malaya, Cyprus, and Rhodesia still lay in the future. Second, one had traditions engendered at St. Cyr, the French military academy, which concentrated upon training cadets in the principles of classical European warfare. Indeed, the focal point of the cadet's education (continued at Coetiquidan, after the destruction of St. Cyr by an American bombing raid in 1944) was the re-enactment of the battle of Austerlitz (hardly a suitable training ground for the deltas and forests of Indo-China).

It would, however, be misleading to imply that the French Expeditionary Force and its leaders were totally unfitted either in experience or outlook for the 'geure d'Indochine'. The war was fought largely by 'L'Armee d'Afrique', and 'L'Armee coloniale'. The former, theoretically, was a branch of the metropolitan army ('L'Armee du metropo(e'), but its troops almost never served on the soil of metropolitan France. Indeed, the most renowned unit, the Foreign Legion ('Legion etrangere') was legally ineligible to do so; whilst the other units - Algerian, Moroccan, and Tunisian Rifles ('tirailleurs'), Senagalese infantry from West Africa, and Spahis (desert cavalry) would have found France more alien than Indo-China. Conversely, the colonial army frequently undertook tours of duty in metropolitan France, for many of its regiments were recruited solely from French citizens; its true function, however, was to garrison the Empire. In short, the war was fought by a professional army which had had a great deal of practice in colonial campaigning (although such campaigning was not central to its traditions, as with its British counterpart). Algeria, Madagascar, Tunisia, Dahomey, Senegal, and Indo-China had been won by the sword, whilste the most famous French soldiers of the nineteenth and twentieth centuries - Joffre, Lyautey, Bourbaki, Marchand, Mangin, Gallieni, Burgeaud - had made their reputations in the empire. However, an important factor militated against the flexible adaptation to terrorist tactics. For the most recent experience of the French army, in North Africa, Italy, and Alsace Lorrain, had been within the context of World War 2 military patterns; viz. that of mobility determined by armoured thrusts, and superiority through artillery and air cover. In other words, victory was attained through the weight of military technology, 
which was nullified through the evasive tactics of guerilla warfare. Furthermore the French army sought to avenge its humiliation of 1940; a humiliation to which the key was the practice of 'blitzkrieg' (the lightning assault based upon the combination of air-attack and armoured thrust, popularized in the 1930s in Germany by Guderian, and in the UK by Maj Genl Fuller). Hence, the French military machine had been acclimatized to a context of war totally unsuitable to the present conflict.

The conflict did not focus entirely upon the passage of the convoys to the frontier towns. There, the French fought at a distinct disadvantage; their routes being fixed, their timetables predictable. Naturally, they sought opportunities to place the Vietminh at a disadvantage by capitalizing upon their superiority in certain military attributes; notably, in their possession of heavy weapons, armour and, above all, air power. Through these advantages, they believed, they could create situations in which the communists could not meet them upon equal terms, and organize streeks deep behind Vietminh lines which their adversaries could not anticipate. The first and most ambitious of these operations (code named 'Lea') was unleashed in the Summer of 1947, and followed a pattern which was to become standard. Paratroops, flown in exLuftwaffe JU 52s (all that the French could muster at that time) were dropped onto targets in the Viet Bac, which a combination of intelligence and guesswork suggested were the most likely to house Vietminh leaders and stores of equipment. Simultaneously, French armoured columns began a rapid advance along the forest roads of the north eastern highlands, with the task of linking hands with the paratroops at the earliest possible moment (a miniature Arnhem operation, in actual fact). Operation Lea, for which the Vietminh were totally unprepared, was almost successful - but not quite. The paratroopers arrived at the building which had housed Ho Chi Minh and his staff only an hour after they had left it. However, in this type of operation, there is no difference between near success and total failure. If it does not succeed totally, it is pointless. Indeed, as the French were to learn, failure entails costs which make the initial risk scarcely worth taking; for the withdrawal along the line of advance becomes an agonizing running battle, perpetually punctuated by ambushes. It was the continual failure of such search and destroy missions, crippled because undertaken within the context of conventional war, which bred and reinforced the defensive mentality. However, to reiterate, the Viet Bac retreat of the Viet Minh could have been penetrated by une American Green Beret tactics in Vietnam, counter-guerilla warfare harrassing and debilitating the nascent and partially trained Vietminh irregular forces.

From a general viewpoint, it should be borne in mind that this stage of communist insurgency is the most vulnerable stage of all for the terrorist. Before being forced into this stage (by the inability to compete on a conventional level) he is protected by a degree of anonymity; whilst in the succeeding stage (that of protracted warfare) the terrorist movement has developed stronger military forces. However, in the second phase, he is floundering about in an unprotected element, unsure of himself. He has not yet gained sufficient support from the people, and, whilst a government may not be popular, it may be feared, and even respected. At the guerilla phase, however, the terrorist is neither. Another important reason for an energetic offensive against the terrorist at this phase is that, whilst he may be able to 'live off the land', he invariably has extreme difficulty in obtaining supplies of arms and ammunition.

\section{Protracted Warfare:}

Almost inperceptibly, the guerilla war slips into the next graduation, that of protracted warfare. The dividing line is not always clearly demarcated, as the screen of petty guerilla activity continues unabated. Having developed a sizeable regular armed force, and indoctrinated a large sector of the population, the guerillas are now more confident of themselves, their missions, and their chances of success. Supplies are adequate, cottage industries functioning, and the arms and ammunition situation gives cause for optimism. At this phase, the fighting is done by regional troops and the village militia, still practising guerilla tactics of sudden strikes, then evasion. This phase may be defined as an intensification of the guerilla war. In Indo-China, it spanned the years 1950-2; a period characterized by the supply and arming of Vietminh units by the Red Chinese. The principle Vietminh achievement during these years was the expulsion of the French from RC4 (in September, 1950), at immense cost and with dreadful indignity. Several of the disasters were brought upon the French by their own commanders; particularly the destruction of the garrisons of Cao Bang and That Mhe, which had been ordered to abandon their efforts and retreat along the RC 4. The greatest humiliation followed upon the evacuation of Lang Son, since events shortly revealed it to have been a panic measure and 
one, moreover, which delivered into the hands of the Vietminh sufficient munitions to supply all their artillery pieces during the following two years of fighting. French morale began to visibly decline.

In 1951, however, there occurred serious Vietminh reverses; reverses which, ironically, facilitated the next phase of the conflict. Giap never fully understood the theory of progressions of guerilla warfare as well as his mentor, Mao. Giap, always the headstrong opportunist, was decidedly premature in assuming that the preceding phase of the conflict was over. This approach was illustrated in the premature conventional attack of 1945. It was also to be illustrated again in 1951. For in this year Giap launched a conventional attack once again, with the object of penetrating the delta of the Red River. The result was three battles: Vienh Yen (13-17 January), Mao Khe (23-28 March), and the Day River (29 May-18 June). The ultimate object in all three battles was to penetrate the delta and, in the process, to destroy the fighting morale and capacity of the French forces in the Tonkin province. However, this assumption that the time was now opportune for a general offensive was a serious misreading of the situation. It provided the French Army with the long sought for opportunity of meeting the Vietminh main force in the open, where the former's heavy weapons and, above all, its air arm, could take full effect. It seized the opportunity enthusiastically, and, at the end of June, Giap had returned to the Viet Bac; having lost 9000 soldiers killed and much valuable equipment, having learnt the effect of napalm bombing upon massed infantry formations, and having seen the French Army demonstrate its superiority in the general conventional offensive.

The French response to the failure of the Vietminh assaults confirmed its dedication to the defensive mentality. General de Lattre de Tassigny (who had been summoned to Indo-China in 1950, as part of the purge following upon the military debacle of September, 1950) began to construct a chain of defensive positions which became known as the 'De Lattre line'. This line was to stretch from the sea near Along Bay, along the northern edge of the Delta to Viah Yenh, and then south-east to the sea again near Phut Diem, encircling protectively both Hanoi and Haiphong. It was to consist of numerous small posts, of concrete construction, each held by an infantry section (or squad), and so sited as to be able to provide supporting fire for the flanking positions. Over 600 concrete defensive positions (reminis- cent ot the English blockhouses of the Boer War of 1899-1902, designed similarly to counteract guerilla warfare) were erected within six months, and by the end of 1951 the De Lattre line was almost completed, over 1200 of such positions having been built. (However, the defensive did not totally dominate French strategy in 1951; for all other available troops were formed into mobile groups - 'groupes mobiles' - which, together with the paratroop battalions, were to comprise the main striking force. They were designed to repel Vietminh attacks and also to undertake operations in Vietminh territory. Nevertheless, these new units were further symptoms of the French misconception of the nature of guerilla warfare; for they were mobile in the vehicular sense only, being on wheels or tracks. Hence, they were road - or, at the best, plains - bound, and mountains, forests, paddy fields, and jungle handicapped them; restricting or funnelling their movements, thereby making them extremely vulnerable to ambush tactics.

De Lattre died ot cancer in January, 1952. His leadership in Indo-China had undoubtedly been beneficial in an immediate sense. He had instituted three important military innovations; viz. the 'groupes mobiles', the commando programme (which created French officered anti-guerilla units), and the fortified cordon. These three innovations had re-vitalized the French counteroffensive in Tonkin. Upon his arrival, the French High Command had been prepared to regard the north as so 'pourri' (rotted) as to be untenable; and were preparing to concentrate the Expeditionary Force south of the 17th Parallel. Ironically, however, de Lattre's success engendered the seeds of a profound defeat. For, by winning a half-victory, he had committed his successors to complete it by the intensification of the defensive concept. The apotheosis of this concept was Dien Bien Phu.

\section{Mobile Warfare:}

This stage begins when the guerilla's main force is sufficiently well equipped and trained to be capable of movement in large bodies - of at least divisional size - through difficult country. Mobile warfare may be regarded as being conventional; as such, it is extremely vulnerable to anti-guerilla warfare. For, as soon as conventional warfare is resorted to, orthodox lines of communication are required. Had the vulnerable supply routes, bases, and installations of the Vietminh become subject to anti-guerilla warfare, the Vietminh 
would have had to absorb an increasing proportion of the regular main force to guard them, and so be left with correspondingly fewer numbers of troops to guard the French. However, even if the French had grasped the need for such a strategy, the De Lattre line would have prevented them from implementing such a course of action, in so far as over 20 infantry battalions (100 000 men) were deployed in this long thin line. As a result, the Vietminh were able, by the close of 1953, to menace Laos (having dominated the Thai country on the west bank of the Black River), by a march on Luang Prabang. For the French striking force amounted to only eight mobile groups and seven parachute battalions, whilst the Vietminh had five divisions in the field. In point of fact, the Communists were in almost undisputed control of most of Tonkin outside the De Lattre line; whilst, within the perimeter (which proved to be a sieve), they were either wholly or partially in control of some 5000 of the 7000 odd villages of the Red River Delta. The French response to this situation was an intensification of the defensive concept, which developed into Dien Bien Phu, and heralded the fifth and final phase.

\section{General Offensive:}

Dien Bien Phu was the project of General Henri Navarre, appointed $\mathrm{C}$-in-C of the French Expeditionary Force on 8 May, 1953. Navarre decided that the only safe counter-measure to an invasion of Laos was a direct and offensive blocking movement. He came to the conclusion that the valley of Dien Bien Phu offered an ideal location for a 'base aero-terrestre' (land-air base). Dien Bien Phu was the largest valley on the frontier with Laos, lying astride the must natural communication route between the Viet Bac and Luang Prabang. The valley had been in Communist hands for some time. As a preliminary to a further decision, Navarre ordered it to be recaptured, and in a brisk attack on 20 November, 1953 , it was recaptured in an operation codenamed 'Castor'. This decided Navarre, and in a directive he defined the form his strategy was to assume. 'I have decided to accept battle', he wrote, 'in the north west, under the following general conditions'. These conditions were the centring of the defence of the Tonkin highlands on Dien Bien Phu itself, and the total commitment of the French Air Force to the support of the air-land base. However, the role of Dien Bien Phu was not simply one of passive defence. Its function was central to a two-point interlocking plan. First, the garrison of the base would act as a mooring point to initiate commando raids against the Vietminh in the highlands and their lines of communication. This would function as a 'bait' in order to initiate the second phase of the plan; to lure the Vietminh into a conventional assault upon the French position. Navarre reasoned that the inherent inferiority of the Vietminh meant that they would not be able to match the French weight of weaponry in the classical military posture of attack.

However, the inherent flaws of this plan ensured that, whilst the French base did attract the Vietminh into a conventional assault, it did so precisely because Dien Bien Phu presented a battle scenario totally advantageous to Giap. This was due to three major factors:-

(i) The military geography of Dien Bien Phu was such that it proved a vast prison for its defenders, in which they could be overwhelmed by sheer weight of numbers and firepower. When the Vietminh opened their initial attacks on 13 March, 1954, the garrison was eleven miles long and three miles wide at its broadest, overlooked by thickly wooded, steep, and jagged hills, which rise to about 2000 feet above its floor (itself approximately 1000 feet above sea level.) Advanced from the edge of the forest are a number of smaller heights; some of which had to be excluded for lack of men to garrison them. Not only was the position everywhere 'overlooked' but at several points - notably near Gabrielle, Beatrice, and Anne-Marie - it was actually dominated. These three strongpoints formed parts of a series of defended areas. The principal ones, clustered around the central airstrip, were known as Huguette (to the west), Claudine (to the south), Elaine (to the east), and Dominique (to the north-east). In the centre of this complex was Command $\mathrm{HQ}$. Slightly removed from this central defence complex were four other independent defended areas. Beatrice was situated a little over a mile distant, on the high ground to the north of, and blocking, the road from Tuan Giao, where it ran through a defile in the surrounding low hills. Gabrielle was two miles to the north on the road from Lai Chau and China. Anne-Marie was perched on a feature out in the paddy fields, approximately $1 \frac{1}{2}$ miles to the north-west of the northern end of the central airstrip. These three positions covered the most obvious approaches. Isabelle, the fourth defended area, was situated approximately four miles to the south, close to the smaller auxiliary airstrip. Its main defended locality was surrounded on three sides by the 
Nam Oum river, which ran past Dien Bien Phu, through the plain from north to south (cf. map).

(ii) One had the initially poor French intelligence with regard to the Vietminh's fire power. The geographical position of Dien Bien Phu demanded that its survival was heavily dependent upon French superiority in artillery. The Commander of the garrison's artillery, Colonel Piroth, reasoned that the Vietminh communications prohibited the movement of sufficient numbers of artillery pieces to compete with those of the French; whilst, should they be able to do so, the same logistical problems would prevent the supply of such pieces with sufficient ammunition. Piroth's optimism was founded partly upon the prevailing General Staff's disbelief in the Vietminh's strategic mobility, and partly upon the size and weight of his own artillery. This consisted of twenty four $105 \mathrm{~mm}$ howitzers, a battery of 155 $\mathrm{mm}$ howitzers, three heavy mortar companies, and a battery of four 'quad fifties' (four barrelled .50 inch anti-aircraft machine guns, deadly in an anti-personnel role). However, two closely interrelated factors nullified the French belief in the superiority of thier artillery. The first was the large quantity of field pieces available to the Vietminh. In the woods above the French entrenchments in early March, in addition to the Vietminh 304th, 308th, and 316th Divisions (comprising 28 battalions of infantry and supporting arms), was the presence of the 351st Division (the 'Heavy Division'), modelled upon the artillery divisions of the Red Chinese Army, and containing 48105 $\mathrm{mm}$ howitzers, of the same pattern as the French, $4875 \mathrm{~mm}$ guns, $48120 \mathrm{~mm}$ mortars, probably as many recoiless rifles of $75 \mathrm{~mm}$ calibre, and at least 36 heavy anti-aircraft guns (the presence of which was to be a crucial factor in the siege, in view of the total dependence of the French upon air-supply.) There were also a large number of heavy anti-aircraft machine-guns and their subunits. The anti-aircraft guns were employed above ground in camouflaged positions. The field-pieces, however, had been dug into pits in the mountainside, from which they could bear upon the French positions below, but above all on the airstrip, without their flashes being observed. Integral to the Communist artillery superiority was the Vietminh strategic mobility, which facilitated a steady supply of ammunition. The French intelligence systems in both Hanoi and Saigon remained in apparent ignorance of the new Vietminh road and truck system, which comprised an all-weather road, extending almost to Lai Chau in the highlands (Lai Chau, in turn, was linked to the Chinese supply network); whilst grossly underestimating the capacity of human porterage, the traditional Vietminh supply method, to deliver goods in bulk and speed over long and difficult distances.

(iii) Neither the capacity of the Air Force, nor the resources of the valley were sufficient for the scale of fortification required. Of first priority was the construction of two airfields. The same over-reliance upon airpower which characterized their successors in Vietnam was a feature of the French campaign also. Air power was to be central to both the supply of the garrison and the evacuation of the wounded. The construction of the two airfields required the delivery of 500 tons of pierced steel plate to provide runways. Dispersal facilities for the aircraft required the building of Bailey bridges across the small river in the valley (the Nam Oum), also required for the passage of light tanks; whilst the entire engineering project required the services of several bulldozers and of a complete engineer battalion. However, the airfields, although the most urgent task, were not the most consumptive of time, labour, and materials. The construction of bunkers, trenches, and barbed wire entanglements for the garrison, its services and command, absorbed these three factors of production to its greatest extent. In addition, an underground central headquarters and hospital were essential; as also were water filtration plants (amoebic dysentry being endemic in the campaign), generaling stations, maintenance and repair workshops for tanks and ammunition dumps, and general stores. Around these, which occupied the centre of the camp, had to be drawn a net of barbed wire and trenches; whilst outside them stood the strongpoints of the main defensive system.

However, to provide the tonnage of wood, steel and wire required to strengthen the position to normal operational standards, and to provide shell-proof positions and proper entanglements for the fighting troops, would require over 30000 tons of engineering material. The over-extended 'Armee de L'Air' (consisting of some 80 aircraft) could only make available to the battle daily deliveries of 150 tons, out of which, as a first priority, had to be subtracted food and munitions. Thus, an enormous shortfall in engineering material had to be accepted by the sapper commander at Dien Bien Phu. He therefore decided to ask for the 3000 tons of delivery which he could reasonably expect in the form of barbed wire - which experience of Vietminh human wave assaults had taught the Expedition- 
ary Force was absolutely vital to the survival of defence units. Unfortunately, the resources of the valley provided no substitute at all for all the other commodities required; no cement, no sand, no brick, and (strangely enough) virtually no wood. For the floor of the valley was almost treeless, whilst the wooded slopes were trackless.

Cut timber could not, therefore, be brought down to where it was needed, whilst the presence of Vietminh scouts and skirmishers rendered woodcutting a most hazardous task.

By the last week of 1953, it had become evident that the original purpose of Dien Bien Phu - to compel the Vietminh to concentrate against the valley by conducting commando operations against their lines of supply - had proved totally futile. For at this time the garrison had learnt that it could not safely stray beyond the valley, and during January and February of 1954 it had to devote its efforts increasingly to retain the right of free movement within the valley. Unseen Vietminh units steadily encroached upon the strongpoints, established positions on the minor heights of the valley floor and ambushed any party foolhardy enough to penetrate the forest on the encircling heights. The establishment of the 'aero-terrestial base' had achieved its object, but for precisely the wrong reason from the French viewpoint; it had ranged the French army against its foes within a military context which ensured the defeat of the former with an almost tragic certainty. Dien Bien Phu ensured that Giap could launch the final offensive on levels at which French planning had always calculated him to be weaker than they - at the logistical and strategic levels; it provided him with the opportunity which he had sought, and which had eluded him, in 1945 and 1951. The French had chosen a fortified military stance when its conventional forces could not possibly compete with those ranged against it. Dien Bien Phu could only survive if the fire power ranged against it could be counteracted by its own artillery; but this could not possibly be the case, in view of the decisive tactical advantages which the Communists had evolved behind the screen of guerilla conflict. On the tactical level Giap could command approximately 35000 infantry, 12000 gunners and sappers, and perhaps 50000 coolies in or near the valley. As intimated above, Giap's artillery deployed about one hundred 105 $\mathrm{mm}$ howitzers; the French working total on any one day was between 10 and 18, and replacements for both guns and crews always headed supply priority lists. The French total effective infantry in the main fortress was only some 2600 (comprising five Parachute and two Foreign Legion battalions).

Nor could the French air arm counteract the garrison's deficiency in artillery and personnel, let alone function as an offensive arm. Even at the height of the siege, the French had only 100 Dakotas available in the whole of Indo-China, and 30 of the larger C-119s, flown by volunteer American crews. The average number of aircraft employed to provision the garrison was only between 65 and 80 . As these aircraft were forced, by Vietminh flak, eventually to rely entirely upon parachuting supplies, and to drop from increasingly high altitudes, whilst the area of the camp gradually constricted with the loss of outlying strong points, the quantities of food and ammunition actually received by the garrison often fell below the theoretical minimum of 300 tons daily it required for survival; the average drop, indeed, was only some 175 tons a day. An appreciable portion (perhaps $20 \%$ ) fell beyond the continually diminishing perimeter, into Vietminh hands.

Confronted by an insupportable casualty rate during the first month of the battle (the People's Army suffered approximately 10000 killed and wounded during the period, almost half the eventual total of the battle) the Vietminh resorted to traditional attritional siegecraft. This siegecraft assumed the form of a multiplication of trenches, yielding an encircling belt of continuous entrenchment at some distance from the perimeter of the main camp (familiar to eighteenth century soldiers as 'lines of circumvallation') and, leading inwards from it, a series of spur trenches, the heads of which rested on, and eventually within, the French wire).

An interesting feature of the siege of Dien Bien Phu was the extent to which the French failed to exploit the counter-attack capability of Dien Bien Phu (admittedly limited) which remained potentially effective even within the context of a static attritional conflict. Underlying this point is the question: Could Hanoi and Saigon (the headquarters of General Navarre) have not done more to prepare the garrison for the battle of attrition and position which - by the end of March appeared both inevitable and unavoidable? The answer to this tactical question is that they almost certainly could. Some factors were, admittedly, beyond the power of the French to remedy or supply. The most important factor was, of course, air power. The French Air Force - land and seaborne - was extended to the limits by the 
daily demands of the war, and there were insufficient reserves of aircraft or - the principal limiting factor - aircrew within France itself to alter the situation. However, in assessing the importance of this factor, one should bear in mind that the French High Command committed the usual error (equally evident with regard to the Americans a decade later) of over-estimating the strategic capabilities of air power. The weight of bombs dropped along the Vietminh approach routes to Dien Bien Phu - some 600 tons on 200 miles of Routes 41 and 13 - was virtually wasted; for, although the Vietminh were compelled thereby to deploy much labour in order to camouflage and repair the damaged roads, for the Vietminh the supply of labour was never a problem, and the supplies which were precious to them were not seriously affected by the sporadic and almost random bombing. The French would, therefore, have been far better advised to restrict their bombing effort to the valley itself, a course of action which would not only have proved tactically more effective, but, simultaneously, would have economically husbanded extremely limited resources. Within the valley itself, a more realistic tactical approach could have been adopted. First, a better lay-out of the position could have been executed. The outlying positions to the north of the central airstrip - Anne Marie, Beatrice, and Gabrielle - should probably never have been occupied (nor, indeed, Isabella, to the far south of this airstrip). This would, admittedly, have permitted the Vietminh to approach closer to the central airstrip, from the outset, but would simultaneously have provided the French with 4 additional battalions with which to launch counterattacks from the central position. This particular criticism of the French tactical approach at Dien Bien Phu embodies a profound indictment of their entire strategic approach in the Indo-China War; for it exemplifies the static-defensive mentality which afflicted French planning throughout the war. Castries (who initially commanded the garrison) and his superiors chose to fight a strategically static campaign at Dien Bien Phu in a tactically static manner. For how was the French plan for Dien Bien Phu, once they had abandoned their hopes of utilizing it as a commando base, any different from those for the defence of Verdun in 1916? For it allocated the cardinal role to artillery, and consigned the infantry to the function of mere trench filling. Thus, the ghosts of Nivelle and Petain overshadowed Dien Bien Phu.

One should remember that intelligence had provided Navarre and Cogny (De Lattre's Chief of Staff) with a remarkably accurate estimate of the
Vietminh's numbers and stocks of supplies some days before the closing of the central airfield in mid-March. This estimate should have patterned the response of the garrison. This pattern should have centered upon what might be termed the 'counter-attack capability' of the garrison. Langlais and Bigeard (who conducted the campaign in its later phases) were able to sustain the defence for as long as they did by concentrating upon counter-attack tactics. These tactics were successfully realized due to the possession of tanks and the dedication of a small number of parachute and Foreign Legion battalions. In retrospect it is easy to discern, therefore, that Castries should have been sent, in early March, a further 10 or 20 tanks (or, indeed, as many as could have been flown in and re-assembled), and two or three of the parachute battalions which were fed to him in small segments over the ensuing two months. Moreover, it need not have been necessary to construct new positions for these counter-attack troops. The banks of the Nam Oum River, could have functioned as a base for a central reserve (as, indeed, it functioned as a refuge for deserters, popularly known as 'rats'). Further factors reinforce the viability of the counter-attack approach. The airfield could probably not have been kept open any longer than it actually was. However, as Bernard Fall ${ }^{1}$ points out, the Vietminh's anti-aircraft artillery, much of which was short range and therefore had to be emplaced close to the airstrip itself, provided an ideal target for counter-strikes from the main position. (One such sally was brilliantly organized and executed by Bigeard on 28 March). Moreover, the Vietminh's stock of such weapons was finite. Thus, each loss inflicted upon the enemy's artillery would therefore have reduced by that amount the enemy's capability to interdict the camp's re-supply. The need to protect their anti-aircraft artillery against tank and infantry assaults would have also over-extended Giap's infantry resources, resulting in his being able to launch either few or weaker assaults in the trenches and strongpoints on the perimeter, which, in turn, would have exacted even higher casualties from the Vietminh's human wave assaults.

Assuming that the French defence of Dien Bien Phu had, indeed, been structured upon such motivating principles, the battle may well have assumed the following pattern:-

The airfield would have been closed by Vietminh bombardment at approximately the time it was (between 13 and $25 \mathrm{March}$ ), and the anti-aircraft 
artillery would have been advanced close to the perimeter in order to compel the aircraft ferrying the parachuted supplies to fly at their maximum height. At approximately the same time, Giap would have launched a series of mass infantry attacks on one or more of the outlying strongpoints. probably on those situated on the five hills' flanking the garrison. which denied him close range observation of the interior of the camp from the east. These attacks, however, would have been repulsed with heavy loss to the Vietminh, partially by the fire of small arms and heavy machine guns, and partially by artillery shelling which, from its improved position, would have been able to support the infantry, even though itself under counter-battery fire. In the immediate aftermath of a successful repuls, the tanks and infantry of the central reserve would have launched heavy punitive raids on the Vietminh anti-aircraft positions in the flat land to the west or south of the garrison, destroying or capturing as much material as possible. The subsequent retreat of the Vietminh would have expanded the dropping zone required by the Air Force to deliver parachuted supplies. The retreat would only have been of a temporary nature, however, and localized in character. Nevertheless, the necessity to bear the French counter-attack capability constantly in mind (having been successfully demonstrated) would have probably compelled the Vietminh to resort to trench warfare. This situation actually occurred, as intimated above. However, had entrenched camp warfare been the result of the hypothetical situation discussed above, the Vietminh would not have been able to contract the perimeter of the garrison to the extent to which, in actual fact, they achieved. The French, utilizing their interior lines, would have inflicted upon the Vietminh a succession of minor defeats, employing their high quality infantry in co-operation with tanks. By this means (which would also have arguably strengthened the waning morale of the less dependable battalions in the garrison), the battle may well have been sustained - at a heavy but not insupportable cost in French casualties - to the point at which the Vietminh, provoked by desperation, would have been goaded into executing - and quite possibly miscarrying - a premature all out assault.

However, such an argument possesses immediate relevance only in so far as the failure to pursue a more imaginative organization of the defences of Dien Bien Phu embodied the fatal defensive mentality of the French High Command which so marred the entire response to the Indo-Chinese insurgency. The argument is essentially academic for three fundamental reasons:-

(i) The hypothetical course of the battle discussed above never occurred. By March 17/18 the outlying positions of Gabrielle, Beatrice, and Anne-Marie had fallen; the former two to Vietminh assault, Anne-Marie when the Thai battalion which had been the backbone of its defence deserted. The loss of Gabrielle and Beatrice especially was a death-blow to the garrison, since the Vietminh could thenceforth advance their trenches to the very edge of the airfield and subject the interior of the central position to direct small arms and mortar fire. Beneath the combined weight of intensive artillery fire and human wave assaults of infantry in mass formation, which broke the barbed wire of the defensive perimeter under the sheer weight of corpses, the contracting perimeter of the central garrison disintegrated.

(ii) The most probable result of the battle, had it assumed the hypothetical form discussed above, would have been a gradual withdrawal of the French from the valley; a course of action whicn could not have materially altered the subsequent course of the war.

(iii) Even had the French effected the destruction of Giap's main forces, and even if the news of their destruction had seriously depressed the morale of the regular and regional Vietminh units elsewhere, the overall inbalance of strength between the two adversaries. and the extent of the 'pourissement' in the countryside, had rendered the reestablishment of French authority, in Tonkin at least impossible. Thus, a tactical success at Dien Bien Phu could never have offset the strategic disaster embodied in the IndoChina War.

On May 8, 1954 the Vietminh stormed the central position, and tne garrison finally surrendered. The fall of Dien Bien Phu left the Vietminh in total control of Tonkin, and this victory was recognised in the terms of the Geneva Convention (which first sat on the day Dien Bien Phu fell). The convention awarded Tonkin to the Vietminh. Annam and Cochin-China were also awarded independence, and Laos and Cambodia demilitarized unaer internatinnal supervision. The. French empire in the Indo-China Peninsula was no more. The terms of the convention polarised the partion of North and South Vietnam. This partition, 
however, may have closed the five act tragedy of French Indo-China, but it necessitated two further epilogues - the absorption of South Vietnam by the Communist North (inevitably so once the American evacuation removed all obstacles to an innately aggressive and expansionist ideology), and the loss of both Cambodia and Laos to Communist dissidents. The fall of the northern province of Tonkin in 1954 was thus the initial stage of the domino strategy in South-East Asia.

Perhaps the most unusual feature of the entire war was the total absence of political direction motivating the French. The recognition by France that the republic of Vietnam was an independent state led to a situation in which the French forces were fighting for a nation which had been politically relinquished. (A similar situation occurred in Malaya). Since the June of 1948 , Vietnam had held the status of an independent associated state within the French Union of Indo-China, under the rule of Bao Dai, who had renounced his title of Emperor and assumed that of. Head of State. Laos and Cambodia were equally and simultaneously recognized as associated states under the rule of their respective kings. The French expeditionary force thus fought in an ideological vacuum; there was no real ideological counter-offensive against the systematic mass-indoctrination of the Vietminh. In view of this vacuum, the only loyalty which the French Army could develop was to itself; indeed, its loyalty was even more parochial than this, ultimately residing in its close-knit regimental loyalties. This process was intensified by two further factors. First, the force had an all-regular or volunteer content, thereby leading to a remoteness from the French populace. This factor was compounded by the preponderantly alien content of the force; North African, Indo-Chinese, and Foreign Legion troops (whose ethnic base was German) were used so extensively that Frenchmen hardly felt themselves involved (unlike the Algerian conflict, in which virtually every family in the land was involved). Secondly, one had internal subversion, emanating from an uncensored left-wing press and the French Communist Party. The former played a major role in developing a mood of defeatism, and inducing into the political psychology of the nation the concept that capitulation was the only rational course. The French Communist Party took opposition to the war to the length of sabotaging equipment en-route to Indo-China at the shopfloor level. Indo-China led ultimately to the French Army's regarding itself as a state within a state.
This approach was further nurtured in Algeria. In this state the Army, having learnt the lessons of Indo-China, had unarguably won war against the F.L.N., by 1960 . Thus, De Gaulle's decision to treat with (i.e. to surrender to) the nationalists so violently outraged the sensitive pride of the Foreign Legion and parachute regiments that its feeling of alienation from metropolitan France became total. The result was that the Army became a political force in the conspiracy (known as the OAS) of 1961, which endeavoured to retain Algeria as a French possession.

(The mdependent spirit of the French paras had been notable at Dien Bien Phu, where the leaders of the Parachute unit, the 'Groupement aeroporte 2' (Bigeard. de séquin-Pazzis. and Langlais) disputed and ultimately usurped the authority of Colonel Christian de Castries. No one disputed Castries' personal courage. However, although he had escaped from a German POW camp, and fought throughout the liberation campaign, he did not really belong temperamentally to the "new army'. Like many gallant and successful French officers (including, perhaps, Navarre and De Lattre), he subscribed to the philosophy of combat in which respect for conventions and gentlemanly conduct were ultimately more important than the issue of victory - concepts anethema to successful COIN operations. Such singular class loyalties were violently antipathetic to the officers of GAP 2, many of whom derived from humble social backgrounds. Bigeard, for example, perhaps the most famous battalion commander in Indo-China, was the son of a railwayman, and had risen from the ranks by the display of outstanding courage and command ability. All were injected with the aggressive and highly individualistic 'para spirit'. The impression that Castries' leadership was motivated by the concept of an 'honourable defeat' prompted Langlais, commander of GAP 2, and other parachute officers, to relieve Castries of his command.) It is hardly surprising, therefore, that in the OAS conspiracy one finds the names of Guirand, Brechnign, and Botella, three of the heroes of Dien Bien Phu.

- S. Monick, MA, Ph, D., FSA (Scot), FRSA

\section{Blbliography}

1. Fall, Bernard:Hell is a very small place; the siege of Dien Bien Phu. London. Pall Mall Press, 1966.

2. O'Ballance, Edgar: The Indo-China War, 1945-54; a study in guerilla warfare. London : Faber, 1964.

3. Breaking our chains (Documents, etc.) Hanoi: Foreign Languages Publishing House, 1962.

4. (iii) Giap, Vo Nguyen: Dien Bien Phu. Hanoi: Foreign Languages Publishing House, 1962.

5. Miksche, F.O.: Secret Forces. London: Faber, 1950. 